\title{
GRANGER CAUSALITY BETWEEN STOCK RETURNS and TRADING VOLUME: EVIDENCE FROM AN EMERGING MARKET
}

\author{
Erdinç ALTAY $Y^{l}$, Ferda YERDELEN ${ }^{2}$

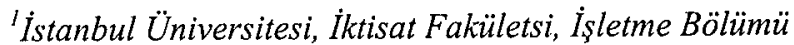 \\ ${ }^{2}$ Istanbul Üniversitesi, İktisat Fakületsi, Ekonometri Bölümü
}

\begin{abstract}
Özet: Bu makalede 1993-2000 yillart arasında IMKB'de işlem gören hisse senetlerinin getiri oranlart ile piyasaya giren bilginin bir göstergesi olarak kullanulan işlem hacmi değişim orant arasındaki Granger nedensellik ilişkisi araştırtlmış, yeni bilgi girişinin varlık getiri oranlart üzerindeki gecikmeli etkisi incelenmiştir. Çalışmada iki ayr VAR süreci kullantlarak getiri oranlart ile işlem hacmi arasında iki yönlii Granger nedenselliğin varlığı konusunda deliller elde edilmiştir. Getiri oranlarının mutlak değerleri ile işlem hacmi arasındaki nedensellik, sözkonusu dönende hisse senetlerinin \% 89'unda anlaml bulunmus, tïm hisse senetlerinin getiri oranlarmın ise gecikmeli getiri oranlart ile anlamll bir ilişkisi olduğu tespit edilmiştir. Ulaşılan sonuçlar, piyasaya giren bilginin gecikmeli olarak fiyatlara yansıdı̆̆ı yönündedir.
\end{abstract}

\section{INTRODUCTION}

The effect of information in capital markets is an important issue that should be considered in various finance theories. The importance of information effect can easily be understanded by simply observing new empirical tests of various models that employ dynamic structure in the sense of including information arrival to the theoretical frameworks and comparing the results with static ones'. For example two basic asset pricing models; Capital Asset Pricing Model (CAPM) of Sharpe [1]; Lintner [2] and Mossin [3]; and Arbitrage Pricing Theory (APT) model of Ross [4] have a great number of empirical literature that tests the validity of the models in capital markets both in the form of dynamic (conditional) and static (unconditional) forms. A literature review shows that conditional tests that considers the effect of information flow on risks and returns (for example: Ferson, Kandel and Stambaugh [5]; Bollerslev, Engle and Woolridge [6]; Harvey [7]; Bodurtha and Mark [8]; and $\mathrm{Ng}$ [9] for CAPM and Ferson and Harvey [10]; and Ferson and Korajczyk [11] for APT) overperform unconditional tests in the sense of capturing theoretical arguments in empirical results and rejecting static structure of risk return relation.

The inclusion of information effect on asset returns and risks in price generation process can be seen in two basic forms. First form can be described as Autoregressive Conditional Heteroscedasticity (ARCH) or Generalized Autoregressive Conditional Heteroscedasticity (GARCH) framework that are generally employed in conditional CAPM tests, and the second form can be described as the use of dynamic structure of "instrumental variables" in pricing models which can generally seen in conditional APT tests.

Another important theory that deals with the direct effect of information flow on asset returns, instead of riskreturn relation, is "Efficient Market Hypothesis". Fama [12], described information in three categories and defined the level of efficiency in capital markets theoretically. A great number of empirical studies in so many different capital markets employed various kinds of analysis methods changing between filter rules to serial correlation tests in order to examine the level of information effect on prices and the speed of price adjustment process.

The importance of information arrival on asset returns is clear. So the determination of an "information flow proxy" and empirical identification of asset returninformation proxy relation can provide useful results in order to include information factor in various models and appreciate the predictive power and/or to get empirical evidence to various theories. In finance literature, trading volume is widely used as a proxy of information flow in the market. Several studies examining trading volume as information arrival belongs to Clark [13]; Copeland [14]; and Epps and Epps [15].

There are some studies on discovering the direct relation between volume and return of assets. Hiemstra and Jones [16] implemented Linear and Nonlinear Granger Causality test in order to examine the predictive powers of past trading volume on asset returns and past returns on trading volume. They found evidence of linear Granger Causality towards asset returns to trading volume and nonlinear Granger Causality towards both returns to trading volume and trading volume to returns. 
There are also some examples of implementing trading volume as a proxy of information arrival into asset pricing models; for example Solibakke [17] tested conditional CAPM by a Bivariate ARMA-GARCH-inMean system on volume based asset portfolios in Norwegian Equity Market. Another paper investigating GARCH and Volume effect is written by Lamoureux and Lastrapes [18]. According to the paper, daily asset returns are generated by a mixture of distributions captured by a GARCH system where trading volume is a proxy of stochastic mixing variable which represents daily information arrival.

Another use of trading volume is seen in Chordia and Swaminathan [19]. In the paper, the effect of trading volume on explaining cross-autocorrelations of asset returns and, the hypothesis of significant relation between trading volume level and reaction to information arrival are examined. As a result, evidence of significant effect of trading volume as a determinant of the lead-lag patterns observed in stock returns is found. On the other hand Blume, Easley and O'hara [20] investigated the informational role of volume and the statistical properties of volume and market prices.

Examination of predicting power of trading volume on asset returns can be seen in Karpoff [21]; Gallant, Rossi and Tauchen [22]; Jain and Joh [23]; Rogalski [24]; and Smirlock and Starks [25].

In this paper, Granger causality between trading volume and asset returns in Istanbul Stock Exchange (ISE) is examined in the period between 1993-2000. Returns and increase rates of trading volumes of 82 stocks that are continuously traded in the above stated period is examined in a Vector Autoregressive (VAR) model framework. This study provides additional empirical evidence on the relation between stock returns and trading volume in ISE. The paper proceeds as follows. Section.2 briefly presents basic theoretical explanations of return volume relation, Section. 3 describes the analysis method, Section. 4 describes the data used in the paper and Section. 5 states the empirical results reached from the analysis procedure.

\section{BASIC THEORETICAL EXPLANATIONS of RETURN-VOLUME RELATION}

Trading Volume is considered as an important issue in understanding capital markets. In finance literature, there are two basic approaches answering the question of "Why investors trade" and modelling trading phenomenon in Capital markets. First approach is built on rational investor assumption. According to these models, rational investors trade because of their different information, endowments, beliefs, preferences and tastes. So, heterogeneous rational investors value assets differently and trade when two investors have different opinions about the value of same asset. Second approach on trading is based on irrational investor assumption. According to this approach, investors generate some trading rules that is inconsistent with rational behaviour like buying when other buy or selling when others sell. There are also some other motives for trading besides heterogeneous preferences and irrational trading strategies like; liquidity and hedging motives.

There are several basic theoretical explanations on the causal relation between asset returns and trading volume. These explanations can be seen as; mixture of distributions hypothesis; sequential information models; tax and non-tax related motives for trading.

The mixture of distributions hypothesis of Clark [13]; Epps and Epps [15]; Tauchen and Pitts [26]; and Harris [27] provides explanations on empirical distributions of stock prices assuming that there is a positive relation between return and volume of a transaction. While in the model of Clark [13], volume is used as a proxy of information arrival, Epps and Epps [15] used volume as a measure of disagreement between traders on stock prices based on the information arrival to the market. They suggested a model where price generation process is a result of interrelation of volume and return.

Sequential Information Model of Copeland[14] examined a theoretical framework in which changes in investor expectations cause a dynamic price adjustment process in asset trading volume and prices. In the model, new information arrives sequentially to investors. So as the investor get information sequentially, some are informed while some others are not informed yet at a time. Thus, in a sequential information arrival process, a new information reaches to an initial investor, cause his/her to trade and change volume and price, after this initial price adjustment process a second investor gets the information and reacts by trading, changing volume and price. This process continues until all investors reaches to the information and adjust a final equilibrium through trading. This structure cause increase in trading volume and price movements after the new information arrival into the market based on informational shocks.

Sequential Information Model is modified by Jennings, Starks and Fellingham [28] with the addition of margin constraints, short sales and a theoretical price adjustment framework that employs information arrival, price change and trading volume relations. In the model, a positive causal relation between stock prices and trading volume is suggested.

According to the sequential information model, a lagged relation between asset returns and trading volume cause a predictability of absolute values of current return by lagged values of trading volume; and trading volumes 
by lagged values of absolute asset returns (Hiemstra and Jones [16]).

Lakonishok and Smidt [29] examined another source of possible volume-return relation based on tax and non-tax related motives for trading and suggested a positive relation for non-tax trading motives and a negative relation for tax related trading motives. On the other hand, Admati and Pfleiderer [30] show that large trading volume attracts investors to trade. According to this model, an increase in trading volume cause a further increase in trading and generates a change in asset prices. So the level of volume is significant in volume-price movement relation.

\section{METHODOLOGY of GRANGER CAUSALITY TESTING}

Causality testing based on the examination of whether past values of a variable is significant in explaining another current variable started generally in 1960's. In these years, another kind of an analysis, Vector Autoregressive Regression (VAR), is also utilised widely in econometric literature. In a VAR process, models for all variables are constructed as it is a linear combination of its own and another variables' lagged values. Such a relation is called as an Autoregressive Distributed Lag (ADL) relation. The most important feature of the VAR process is the exclusion of "endogeneous" and "exogeneous" variable differentiation, and acceptance of all variables as endogeneous variables (Gujarati [31]). The exogenous variables employed in the process are just lagged values of endogenous variables (Kennedy [32]).

VAR process can be shown as follows:

$$
\begin{aligned}
& X_{i, t}=\lambda_{1}+\alpha(L) X_{i, t-k}+\beta(L) Y_{i, t-k}+\varepsilon_{1, t} \\
& Y_{i, t}=\lambda_{2}+\gamma(L) Y_{i, t-k}+\eta(L) X_{i, t-k}+\varepsilon_{2, t}
\end{aligned}
$$

In the first regression model, if lagged values of $Y$ can predict $X$, controlling for the predictive power of lagged values of $X$, than $Y$ is said to Granger cause $X$. On the other hand in the second model, $X$ is said to Granger cause $Y$ if the lagged values of $X$ can predict $Y$, controlling for the predictive power of lagged values of $Y$.

Matrix form of $\operatorname{VAR}(\rho)$ process can be shown as;

$$
\begin{aligned}
& {\left[\begin{array}{l}
X_{i, t} \\
Y_{i, l}
\end{array}\right]=\left[\begin{array}{l}
\lambda_{1} \\
\lambda_{2}
\end{array}\right]+\left[\begin{array}{ll}
\theta_{11,1} & \theta_{12.1} \\
\theta_{21.1} & \theta_{21.1}
\end{array}\right] \cdot\left[\begin{array}{l}
X_{i, l-1} \\
Y_{i, t-1}
\end{array}\right]+\ldots+} \\
& {\left[\begin{array}{ll}
\theta_{11 . k} & \theta_{12, k} \\
\theta_{21 . k} & \theta_{22 ., k}
\end{array}\right]\left[\begin{array}{l}
X_{i, t-k} \\
Y_{i, t-k}
\end{array}\right]+\left[\begin{array}{l}
\varepsilon_{1 t} \\
\varepsilon_{2 t}
\end{array}\right] }
\end{aligned}
$$

VAR process can be tested by using $t$ statistics. In order to perform causality test by a VAR process, a regression is run between current $X$; and lagged values of $X$ and $Y$ variables. If the coefficient of last lagged $Y$ variable is statistically insignificant, then it is said $Y$ do not cause $X$; but on the other hand if one or more than one lagged coefficients of $Y$ variable is statistically significant according to t-test, than it is said: $\mathrm{Y}$ cause $\mathrm{X}$ (Jonston and John [33]).

VAR process can also be tested by using Granger Causality test (Granger [34]) that is based on F-statistics. Granger causality test hypothesis can be constructed as follows:

$\mathrm{H}_{0}: \theta_{12,1}=\theta_{12,2}=\ldots .=\theta_{I 2, p}=0$ (lagged $\mathrm{Y}$ should be excluded from the model)

$\mathrm{H}_{1}$ : At least one of the follows $\theta_{12,1} ; \theta_{12,2} ; \ldots ; \theta_{l 2, \rho}$ is not equal to zero

Null hypothesis $\left(\mathrm{H}_{0}\right)$ can be tested by an F-statistic which is calculated as a ratio of residual sum of squares of two different regression models. In the first model, $X$ regress on all lagged $X$ terms and other variables, if any, but do not include the lagged $Y$ variables. Residual sum of squares got from this model is "restricted residual sum of squares $\left(R S S_{R}\right)$ ". Another value of "unrestricted residual sum of squares $\left(R S S_{U R}\right)$ " is got from a second model where $X$ is regressed against both lagged values of $X$ and lagged values of $Y$.

$$
F=\frac{\left(R S S_{R}-R S S_{U R}\right) / m}{R S S_{U R} /(n-k)}
$$

In the equation; $\mathrm{n}$ is observation number, $\mathrm{m}$ is number of lagged $Y$ terms, $k$ is the number of parameters estimated from the unrestricted regression model. Above stated $F$ values follow $F$ distribution with $m$ and $n-k$ degree of freedom (Gujarati [31]).If the computed $F$ value exceeds the critical $\mathrm{F}$ value, $\mathrm{H}_{0}$ is rejected; $\mathrm{Y}$ is said Granger cause $X$, otherwise in the case of acceptance of $\mathrm{H}_{0}$; $\mathrm{Y}$ is said not to Granger cause $\mathrm{X}$.

A similar hypothesis can also be constructed for $Y$ in order to test a causality relation towards $X$ to $Y$ (Darnell [35]). On the other hand, in the case of analysing a bivariate system where $\mathrm{X}$ is caused by $\mathrm{Y}$ and $\mathrm{Y}$ is caused by $X$; is called feedback system (Judge et.al.[36]). Tests based on VAR analysis are sensitive to nonstationaries in time series so another point that should be noted about the analysis is the necessity of normal distribution and stationary conditions for time series data (Judge et.al.[36]). 


\section{DATA and SAMPLE PERIOD}

Previous works on volume-return relation employ different kinds of data in the analysis. Hiemstra and Jones [16] used continuous stock returns from daily closing prices for the Dow Jones Price Index and continuous change in total daily trading volume on the NYSE. On the other hand Campbell, Grossman and Wang [37] used daily return on a value weighted index of stocks traded on the NYSE and AMEX, Dow Jones Industrial Average and 32 individual stocks. They used "turn over" or "relative volume" (ratio of the number of shares traded to the number of shares outstanding) as volume variable.

In this paper, daily return and trading volume data of common stocks that are traded in Istanbul Stock Exchange (ISE) between 1993-2000 period is analysed. Data are belong only to eighty two stocks which are continuously traded in the full period of 8 years.

In our analysis, daily stock return series are prepared as continuous rates of return which are computed as the first difference of natural logarithm of daily closing stock prices. Daily closing prices are adjusted according to the stock splits and dividends;

$$
R_{i, t}=\ln \left(\frac{P_{i, t}+D_{i, t}}{P_{i, t-1}}\right)
$$

where, $R_{i, t}$ is the continuos return of stock $i$ in day $t, P_{1}$ is price of stock $i$ in day $t$, and Di,t, is the dividend paid in day $\mathrm{t}$.

On the other hand, volume series are also computed as continuous changes in daily total trading volume of each stock:

$$
V_{i, t}=\ln \left(\frac{H_{i, t}}{H_{i, l-1}}\right)
$$

where, $V_{i, t}$ is the increase in volume of stock $i$ in day $t$ and $\mathrm{H}_{1}$ is the total trading volume of stock $i$ in day $t$.

Stationarity of data is critical in causality testing, so stationarity of each time series of volume and return for all stocks are examined by a Dickey Fuller test (Dickey and Fuller [38]). As a result, both series of all stocks are found stationary for the time period 1993-2000.

\section{EMPIRICAL TEST RESULTS of VAR MODEL}

\section{V.1. Examining Causality Between Stock Returns and Trading Volume}

In the paper, a VAR process is implemented in order to examine the volume-return relation to investigate whether trading volume, as a proxy of information flow, has a significant effect on stock returns or not.

VAR process enables to examine a relation between two variables from both perspectives as whether volume Granger cause return or not and whether return Granger cause volume or not. So VAR model constructed to analyse return-volume relation can be shown as follows;

$$
\begin{aligned}
& \text { Model.1: } \mathrm{V}_{\mathrm{i}, \mathrm{t}}=\lambda_{1}+\alpha(\mathrm{L}) \mathrm{V}_{\mathrm{i}, \mathrm{t}-\mathrm{k}}+\beta(\mathrm{L}) \mathrm{R}_{\mathrm{i}, \mathrm{t}-\mathrm{k}}+\varepsilon_{1, t} \\
& \text { Model.2: } \mathrm{R}_{\mathrm{i}, \mathrm{t}}=\lambda_{2}+\gamma(\mathrm{L}) \mathrm{R}_{\mathrm{i},-\mathrm{l}}+\eta(\mathrm{L}) \mathrm{V}_{\mathrm{i}, \mathrm{t}-\mathrm{k}}+\varepsilon_{2, t}
\end{aligned}
$$

where, $V_{i, t}$ is increase in trading volume, $R_{i, t}$ is return of stock $i$ in time $t$, and $\varepsilon$ is error term and $L$ is lag operator. Each model can be separated into two sections: in Model.1; $\alpha(\mathrm{L}) \mathrm{V}_{\mathrm{i}, \mathrm{t}-\mathrm{k}}$ is autoregressive terms section and $\beta(L) R_{i, t-k}$ is distributed lag section. On the other hand in Model.2, $\gamma(\mathrm{L}) \mathrm{R}_{\mathrm{i}, \mathrm{l}-\mathrm{k}}$ is autoregressive section, and $\eta(\mathrm{L}) \mathrm{V}_{\mathrm{i}, \mathrm{t}-\mathrm{k}}$ is distributed lag terms section.

The first step of analysis is to determine the optimal lag length. Akaike [39] and Schwarz information criterion are implemented to determine the appropriate lag length of each of stock. As a result, 20 lag structure is found adequate for bivariate lag lengths and two models are constructed with 20 autoregressive and 20 distributed lagged terms for 82 stocks.

At the second stage, in Model.1, $\mathrm{V}_{\mathrm{i}, \mathrm{t}}$ is regressed against 20 lagged $V_{i, t-k}$ terms and 20 lagged $R_{i, t-k}$ terms; and in Model.2, , $R_{i, t}$ is regressed against 20 lagged $R_{i, t-k}$ terms and 20 lagged $V_{i, t-k}$ terms so the 40 parameters and a constant term of each model are estimated for all stocks. t-test of each estimated parameters of the models are examined and statistically significant lagged variables are determined at $10 \%$ level. As it is expected, it is found that each stock has its own lagged return-volume relation structure where some lagged variables did not found significant for a stock are found significant for another one. For this reason, basic model is implemented to all stock data according to their own structures that contains only statistically significant lagged variables. 
So, at the third stage, insignificant lagged variables for each stock are excluded and only significant ones are employed in the regression process. Parameters of each model for each stock are estimated by ordinary least squares (OLS) method. The results are summarised in Table. 1 and Table. 3.

In Table.1, Panel.A summarises the regression analysis results of autoregressive section of Model.l where the lagged variables of both volume and return are examined whether they are significant in explaining trading volume changes in stocks. In Panel.A it can be seen that 1,2,3,4,5,6 and 7 lagged volume variables are significant at $10 \%$ level in determining volume changes of all stocks. On the other hand $96.34 \%$ of stocks' volume has a significant relation with 8 and 9 days lagged volume variable, $90.24 \%$ of stocks trading volume have a significant 10 days lagged volume relation and so on. It can be clearly seen that as the lag length increases, percentage of stocks that have significant lagged volume to volume relation decrease. So it can be said that, as the lag length increase, the effect of past volume changes on current volume decreases consistently. When the signs of significant lagged variables are examined, it is seen that all lagged variables of $1,2,3,4,5,6,7,8,10,11,12,13$, 14,16 and 17 have negative coefficients. That is, there is a consistent negative relation between current volume change and past volume changes. The average of significant lagged variables' coefficients are also shown in the Table. The absolute value of coefficients of lagged volume variables decrease as length of lags increases, so it can be said that as lag length increases, effect of past volume changes on current changes decreases.

Panel.B of Table.1 summarises the results of distributed lag terms $\left(G_{i t}\right)$ section of Model.1. In other words, lagged effects of return on current volume are summarised in Panel.B. It is seen that all stocks have a significant relation between current volume change and 1 day lagged return. $31.71 \%$ of 82 stocks have significant 2 and 3 day lags, $36.59 \%$ of stocks have significant 4 day lags and so on. When the signs of lagged return coefficients are examined, it is seen that all 1,2 and 3 lagged returns have a positive effect on volume. In other words an increase in 1 day lagged return cause an increase in volume change for all 82 stocks. On the other hand, the direction of relation turns to negative after the 5 days lagged relation. Although only a few (4.88\% of 82 ) stocks have a significant volume- 5 days lagged return relation, all coefficients are negative, that means an increase in return cause a decrease in volume after 5 days.

As a result, Model. 1 shows that volume has a strong negative relation with its own lagged variables especially 1 to 10 day lags and a positive relation with 1 day lagged return for all stocks. So null hypothesis is rejected and a significant causal relation towards return to volume is accepted in ISE between 1993-2000 period. This result is also supported by Table.3, where, the percentages of stocks that have at least one significant autoregressive and at least one significant distributed lag coefficients are stated. Table.3, shows that; all stocks have at least one significant autoregressive and one distributed lag coefficients. This result supports the evidence of rejecting the null hypothesis of model one and accepting a causal relation towards return to volume.

Results of Model.2 of the VAR process is summarised in Table. 2 and Table. 3 . Table. 2 shows that nearly $61 \%$ of all stocks have significant 1 day lagged autoregressive relation in stock returns. On the other hand $96 \%$ of significant 1 day lagged return coefficients have a positive sign implementing an increase in yesterdays return cause an increase in today's return. Percentage of significant 2 days lagged coefficients decreases sharply to $15.85 \%$. Other relatively important autoregressive relation is seen in 4 and 10 day lags with having significant positive coefficients for $32.93 \%$ of all stocks. When we look at Table. 3 , it is seen that $95.12 \%$ of all stocks have at least one significant lagged return coefficient explaining current stock returns. Only $4.88 \%$ of 82 stocks does not have an autoregressive relation of returns.

Panel.B of Table. 2 summarises distributed lag section results of Model.2. This analysis is important in the sense of examining volume effect as an information proxy on stock returns. When the distribution of significant lags is examined, it is seen that only $20.73 \%$ of all stocks have 1 day lagged volume-current return relation, $14.63 \%$ of 82 stocks have 2 day lagged volumecurrent return relation, and so on. That means we can not found evidence of a concentration of any lag lengths. On the other hand in Table.3, it is seen that only $69.51 \%$ of all stocks have at least one lagged volume effect on returns leading $30.49 \%$ of stocks have no significant volume-return relation. This result does not give a strong support to reject null hypothesis of significant causal relation towards volume to stock returns in ISE.

\section{V.2. Examining Causality Between Absolute Stock Returns and Trading Volume}

The examined role of trading volume in the paper is "information flow proxy". So, it is expected that when an information flow arrives in the market, it will change stock returns upwards of downwards according to the optimistic or pessimistic character of the information. So, it is thought that an information flow (good news or bad news), cause an increase in volume leading a change in stock returns. It is impossible to differentiate the volume change caused by a good news and a bad news with the available data but when it is known that if volume is a good proxy of information flow, an increase in volume should cause a significant change in current returns (upward or downward). We can examine this model as 
testing a probable significant volume-absolute value of returns relation. So the basic VAR model examined above can be used with absolute value of returns $\left(A_{i}\right)$ as follows;

$$
\begin{aligned}
& \text { Model.3: } \mathrm{V}_{\mathrm{i}, \mathrm{t}}=\lambda_{3}+\delta(\mathrm{L}) \mathrm{V}_{\mathrm{i}, \mathrm{t}-\mathrm{k}}+\phi(\mathrm{L}) \mathrm{A}_{\mathrm{i}, \mathrm{t}-\mathrm{k}}+\varepsilon_{3, \mathrm{t}} \\
& \text { Model.4: } \mathrm{A}_{\mathrm{i}, \mathrm{t}}=\lambda_{4}+\varphi(\mathrm{L}) \mathrm{A}_{\mathrm{i}, \mathrm{t}-\mathrm{k}}+\mu(\mathrm{L}) \mathrm{V}_{\mathrm{i}, \mathrm{l}-\mathrm{k}}+\varepsilon_{4, \mathrm{t}}
\end{aligned}
$$

Summary result of Model.3 can be seen in Table. 4 and Table.6. When Panel.A of Table. 4 is examined, it is clearly seen that all stocks' trading volume has a negative significant relation with its $1,2,3,4$, and 5 days lagged volume variables. This autoregressive relation is also strong for $6,7,8,9,10$ and 11 lags as $98.78 \%$ of 82 stocks have 6 and 7 lagged autoregressive volume relation, $96.34 \%$ of stocks have 8 day lagged relation and so on. This result is consistent with Model.1 where stock returns are used as real changes (not absolute values). Another point consistent with the Model. 1 is the strong negative lagged relation. An increase in 1 to 14 days before cause a decrease in current stock volume change.

Panel.B of Table. 4 summarises the distributed lag results of the analysis. These results are also consistent with Model.1, that is; $76.83 \%$ of absolute value of lagged stock returns are significant in explaining increase in trading volume. But there is no strong evidence of more than 1 day lagged absolute value returns have a significant effect on volume. The signs of 1 day lagged variables' coefficients are positive for all stocks representing a situation where a positive or negative change in stock returns cause an increase in next days trading volume. So it can be said that; investors are sensible to changes in stock returns and gives reaction as buying or selling in the market, thus increasing the trading volume.

We can not reach a strong evidence of more than one day lagged return change effect on trading volume. This result is also consistent with the results of Model.1. When we look at Table.6, a strong relation between lagged values of volume with volume and absolute values of lagged stock returns with trading volumes. All volume variables examined have at least one significant autoregressive and one significant distributed lagged coefficients, indicating a significant causal relation towards stock returns to trading volume.

Model.4 is constructed in order to examine the information flow effect on asset returns. As it is mentioned before it is expected to find statistically significant lagged volume variables on absolute values of stock returns.

In Panel.A of Table.5, results of autoregressive relation is summarised. It is seen that $96.34 \%$ of all stocks have one day lagged autoregressive relation in absolute returns, indicating change in asset returns are widely dependent to previous days' return change. This relation is also strong for 2, 3 and 5 days lag lengths.

Panel.B of Table. 5 states the lag length distribution of volume effect on stock returns. It is clearly seen that there is no frequent concentration on a volume lag length on absolute stock returns, but we can reach a percentage of $89.02 \%$ of all stocks have a significant lagged volume effect on absolute value of stock returns, indicating that an information flow (good news or bad news) significantly effect absolute value of stock returns (change returns up or down). When we compare this ratio to the results of Model.3 where real values of returns are employed in the model, we can see that there is a significant increase in significant percentages from $69.51 \%$ (in Model.3) to $89.02 \%$ (in Model.4), supporting the expected result of "information flow effect on asset returns".

As a result, Model.4 supports evidence of volume effect on asset returns and a linear causality relation from volume to absolute stock returns.

\section{SUMMARY and CONCLUSION}

In the paper, information effect on asset returns in ISE between 1993-2000 period is examined by using VAR process which employs trading volume change as an information arrival proxy. As a result of Granger causality test procedure, lagged values of volume is found significant on explaining price changes of assets.

Stock market data is employed in four linear models of two VAR processes in order to examine the expected significant return-volume relation. In the first VAR framework, continuous changes in volume and asset prices are examined and evidence of Granger causality towards asset returns to volume is found but on the other hand a strong evidence of Granger causality towards volume to return could not be observed. On the other hand, second VAR framework is constructed to the hypothesis of volume, as information arrival proxy, should effect returns for both directions on the basis of the positive or negative nature of the information that cause trading in the market. So the relation between absolute values of asset returns and volume is examined and evidence of Granger causality is reached on both directions towards trading volume to absolute returns and from absolute returns to volume change. As a result, it can be concluded that lagged values of volume is a significant determinant of asset returns but the structure of lagged relation, number of significant lagged volume variables and the length of those variables, is peculiar to each individual asset that makes very hard to suggest a typical lagged volume return structure for entire stock market. Another evidence of lagged information arrival to the market is inferred from the examination of autoregressive 
sections of VAR models in which all assets' returns are found significantly dependent to their own lagged returns.

\section{REFERENCES}

[1] SHARPE, W., "Capital Asset Prices: A Theory of Market Equilibrium Under Conditions of Risk", The Journal of Finance, Vol:19, No:3, September 1964, pp.425-442.

[2] LINTNER, J., "The Valuation of Risk assets and the Selection of Risky Investments in Stock Portfolios and Capital Budgets", Review of Economics and Statistics, Vol:47, February 1965, pp.13-37.

[3] MOSSIN, J., "Equilibirum in a Capital Asset Market", Econometrica, Vol:34, October 1966, pp.768-783.

[4] ROSS, S.A., "The Arbitrage Theory of Capital Asset Pricing", Journal of Economic Theory, Vol:13, 1976, pp.341-360.

[5] FERSON, W.E.; KANDEL, S.; STAMBAUGH, R.F., "Tests of Asset Pricing with Time-Varying Expected Risk Premiums and Market Betas", Journal of Finance, Vol:42, No:2, June 1987, pp.201-220.

[6] BOLLERSLEV, T.; ENGLE, R.F.; WOOLDRIDGE, J.M., "A Capital Asset Pricing Model with Time-varying Covariances", Journal of Political Economy, Vol:96, No:1, 1988, pp.116-131.

[7] HARVEY, C.R., "Time-Varying Conditional Covariences in Tests of Asset Pricing Models", Journal of Financial Economics, Vol:24, 1989, pp.289-317.

[8] BODURTHA, J.N.Jr.; MARK, N.C., "Testing the CAPM with Time-Varying Risks and Returns", The Journal of Finance, Vol:46, No:4, September 1991, pp.1485-1505.

[9] NG, L., "Tests of the CAPM with Time-Varying Covariances:A Multivariate GARCH Approach", The Journal of Finance, Vol:46, No:4, September 1991, pp. 1507-1521.

[10] FERSON, W.E.; HARVEY, C.R., "The Variation of Economic Risk Premiums", Journal of Political Economy, Vol:99, No:2, 1991, pp.385-415.

[11] FERSON, W.E.; KORAJCZYK, R.A., "Do Arbitrage Pricing Models Explain the Predictability of Stock Returns?", Journal of Business, Vol:68, No:3, 1995, pp.309-349.

[12] FAMA, E.F., "Efficient Capital Markets: A Review of Theory and Empirical Work", The Journal of Finance, Vol:25, May 1970, pp.383-417.

[13] CLARK, P., "A Subordinated Stochastic Process Model with Finite Variances for Speculative Prices", Econometrica, Vol:41, 1973, pp.135-155.
[14] COPELAND, T.E., "A Model of Asset Trading Under The Assumption of Sequential Information Arrival", The Journal of Finance, Vol: 31, No:4, September 1976, pp.1149-1168.

[15] EPPS, T.; EPPS, M., "The Stochastic Dependence of Security Price Changes and Transaction Volumes: Implications for the Mixture of Distributions Hypothesis", Econometrica, Vol:44, 1976, pp.305-321.

[16] HIEMSTRA, C.; JONES, J.D., "Testing for the linear and Nonlinear Granger Causality in the Stock Price-Volume Relation", Journal of Finance, Vol:49, No:5, December 1994, pp.1639-1664.

[17] SOLIBAKKE, P.B., "The Conditional CAPM and Trading Volume. Assuming Trading Volume is an Instrument for the Information Flow: The Case of the Thinly Traded Norwegian Equity. Market", Working Paper, Molde College, 1998.

[18] LAMOUREUX, C.; LASTRAPES, W., "Heteroscedasticity in Stock Return Data: Volume Versus GARCH Effects", Journal of Finance, Vol:45, 1990, pp.221-229.

[19] CHORDIA, T.; SWAMINATHAN, B., "Trading Volume and Cross-Autocorrelations in Stock Returns", Journal of Finance, Vol:60, No:2, 2000, pp.913-935.

[20] BLUME, L.; EASLEY, D.; O'HARA, M., "Market Statistics and Technical Analysis: The Role of Volume", The Journal Finance, Vol: 49, No:1, March 1994, pp.153-181.

[21] KARPOFF, J., "The Relation Between Price Changes and Trading Volume: A Survey", Journal of Financial and Quantitative Analysis, Vol:22, 1987, pp.109-126.

[22] GALLANT, R.; ROSSI, P.; TAUCHEN, G., "Stock Prices and Volume", Review of Financial Studies, Vol:5, 1992, pp.199-242.

[23] JAIN, P.; JOH, G., "The Dependence Between Hourly Prices and Trading Volume", Journal of Financial and Quantitative Analysis, Vol:23, 1988, pp.269-283.

[24] ROGALSKI, R., "The Dependence of Prices and Volume", Review of Economics and Statistics, Vol:36, 1978, pp.268-274.

[25] SMIRLOCK, M.; STARKS, L., "An Empirical Analysis of the Stock Price-Volume Relationship", Journal of Banking and Finance, Vol:121, 1988, pp.31-41.

[26] TAUCHEN, G.E., PITTS, M., "The Price VariabilityVolume Relationship on the Speculative Markets", Econometrica, Vol:51, March 1983, pp.485-505.

[27] HARRIS, L., "Cross-Security Tests of the Mixture of Distributions Hypothesis", Journal of Financisl and Quantitative Analysis, Vol:21, March 1986, pp.39-46. 
Haziran 2002.s.105-118.

[28] JENNINGS, R.H.; STARKS, L.T.; FELLINHHAM, J.C., "An Equilibrium Model of Asset Trading with Sequential Information Arrival", Journal of Finance, Vol:36, No:1, March 1981, pp.143-161.

[29] LAKPNISHOK, J.; SMIDT, S., "Past Price Changes and Current Trading Volume", The Journal of Portfolio Management, Vol:15, 1989, pp.18-24.

[30] ADMATI, A.R.; PFLEIDERER, P., "A Theory of Intraday Patterns: Volume and Price Variability", The Review of Financial Studies, Vol:1, Spring, 1988, pp.1-40.

[31] GUJARATI, D., Basic Econometrics, $3^{\text {rd }}$ Ed., McMillan, New York, 1995.

[32] KENNEDY, P., A Guide to Econometrics, $4^{\text {th }}$ Ed., Blackweel Publ., Malden, Maussechusetts, 1998.

[33] JONSTON, J.; JOHN, D., Econometric Methods, $4^{\text {th }}$ Ed., McGraw Hill, Singapore, 1997.

[34] GRANGER, C.W.J., "Investigating Causal Relations by Econometric Models and Cross-Spectral Methods", Econometrica, July 1996, pp.424-438

[35] DARNELL, A.C., A Dictionary of Econometrics, Hants, England, Edward Elgar, 1994.

[36] JUDGE, G. et.al., Introduction to the Theory and Practice of Econometrics, $2^{\text {nd }}$ Ed., John Wiley, New York, 1988.

[37] CAMPBELL, J.Y.; GROSSMAN, S.J.; WANG, J., "Trading Volume and Serial Correlation in Stock Returns", The Quarterly Journal of Economics, Vol:CVIII, November 1993, pp.905-939.

[38] DICKEY, D.A.; FULLER, W.A., "Distribution on The Estimators of Autoregressive Time Series with Unit Root", Journal of The American Statistical Association, 74, 1979, pp.427-431

[39] AKAIKE, H., "A New Look at The Statistical Model Identification", IEEE Transactions on Automatic Control, 19, 1974. 


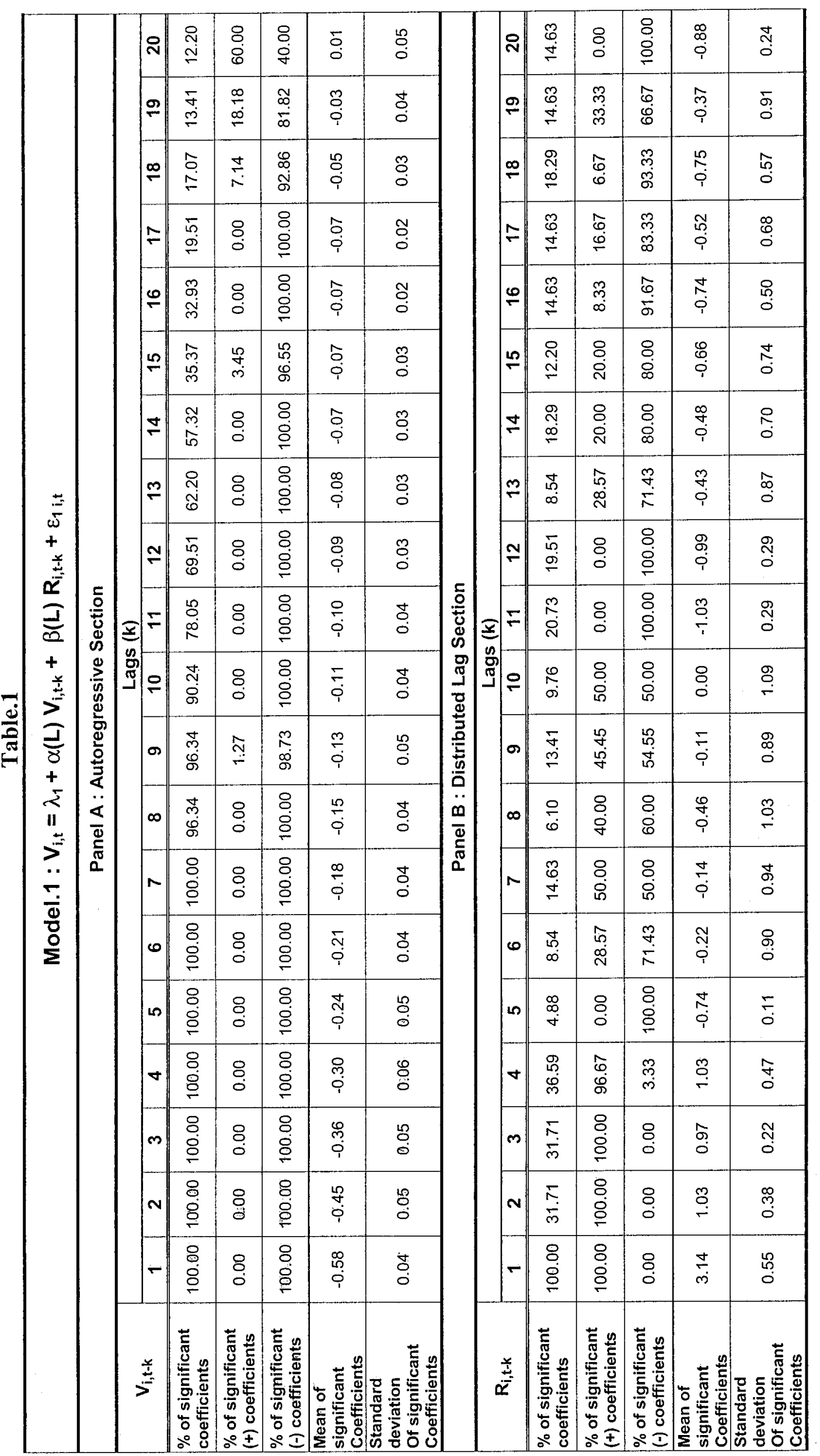




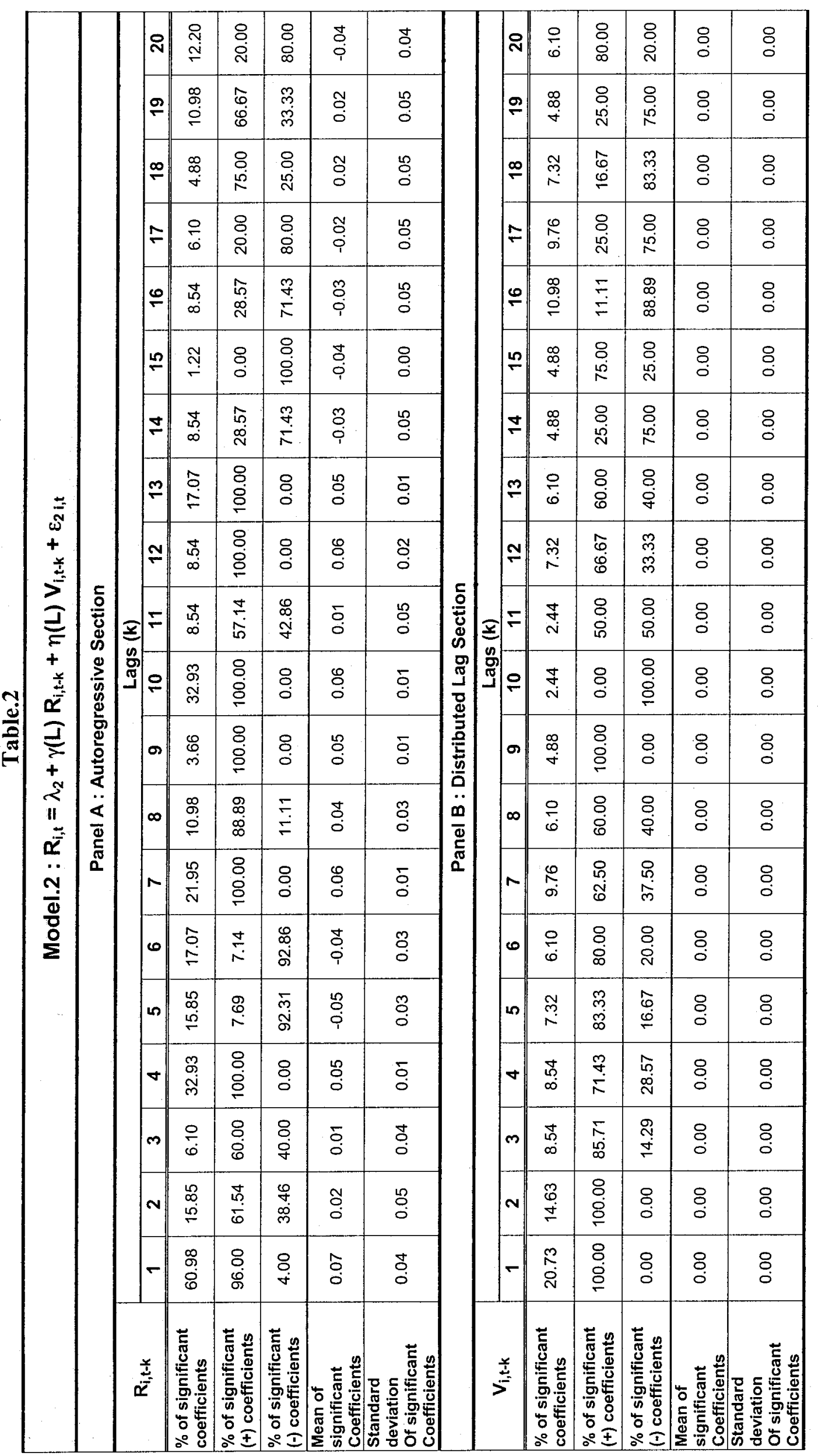




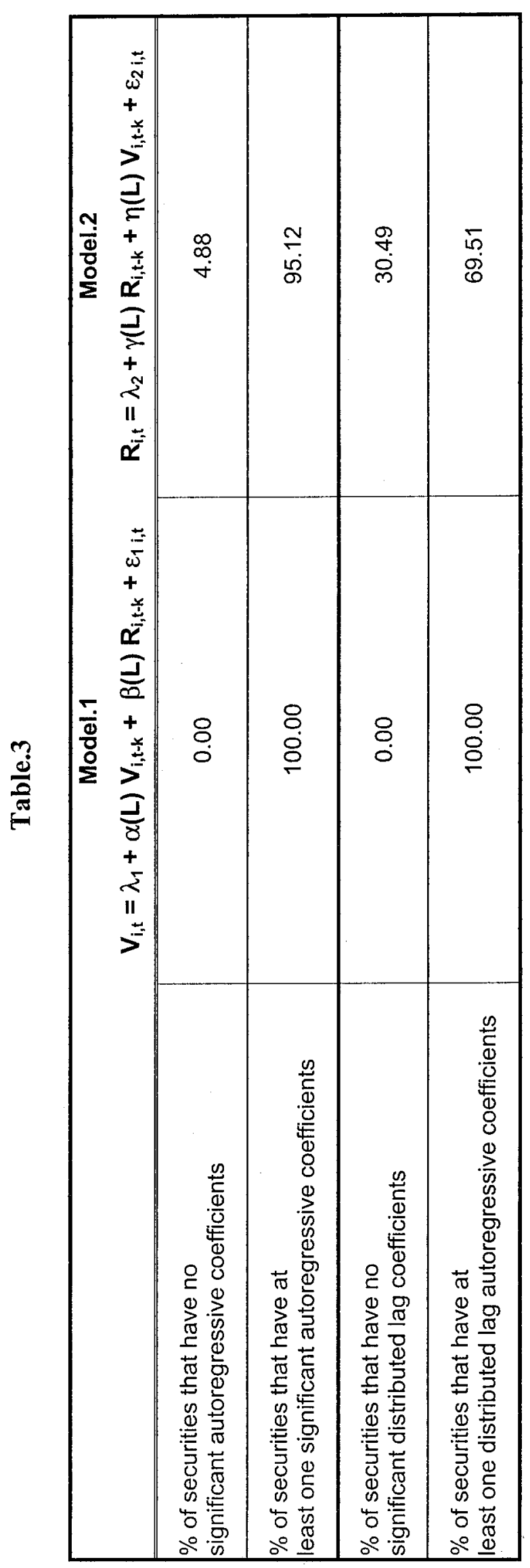




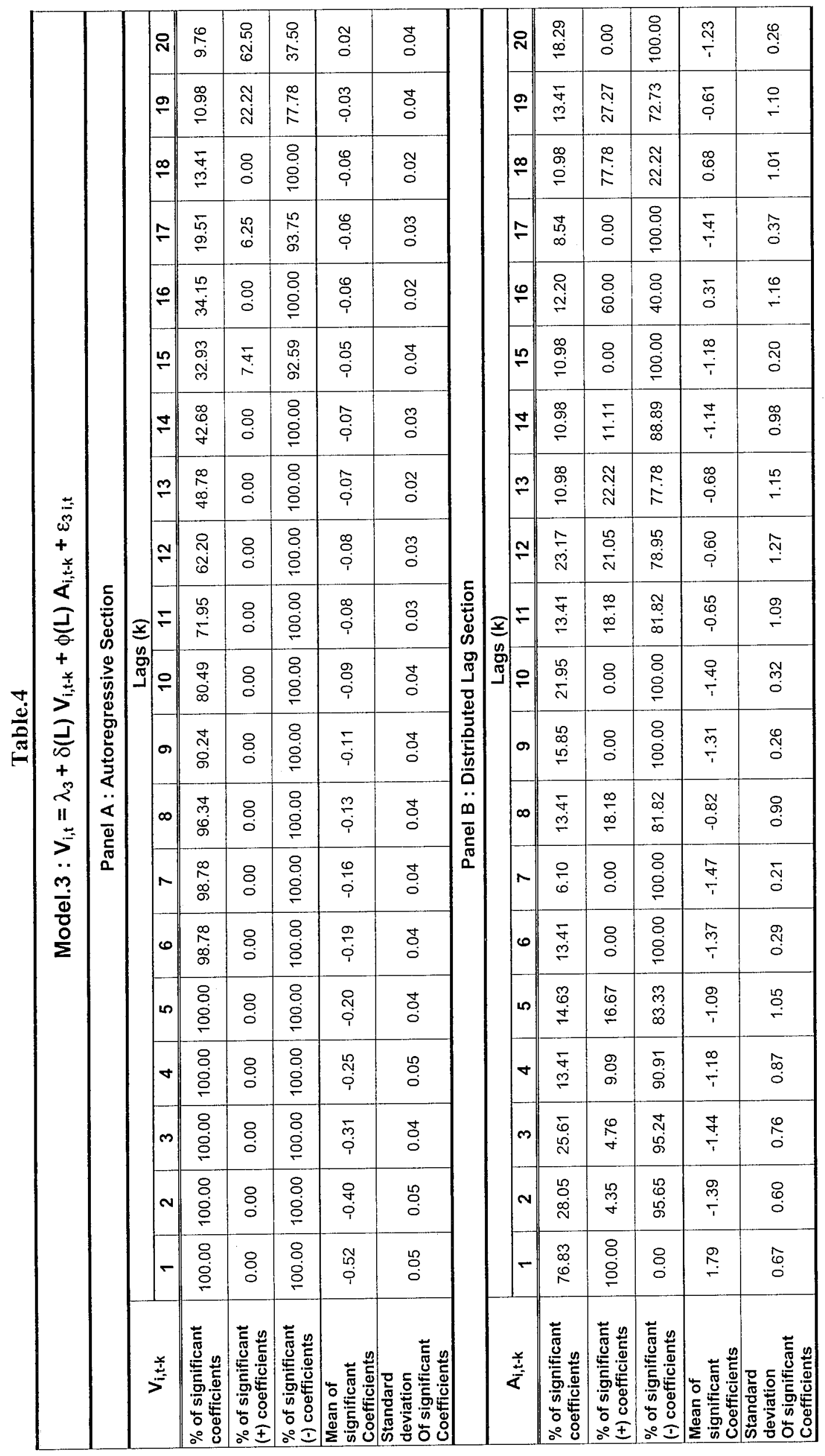




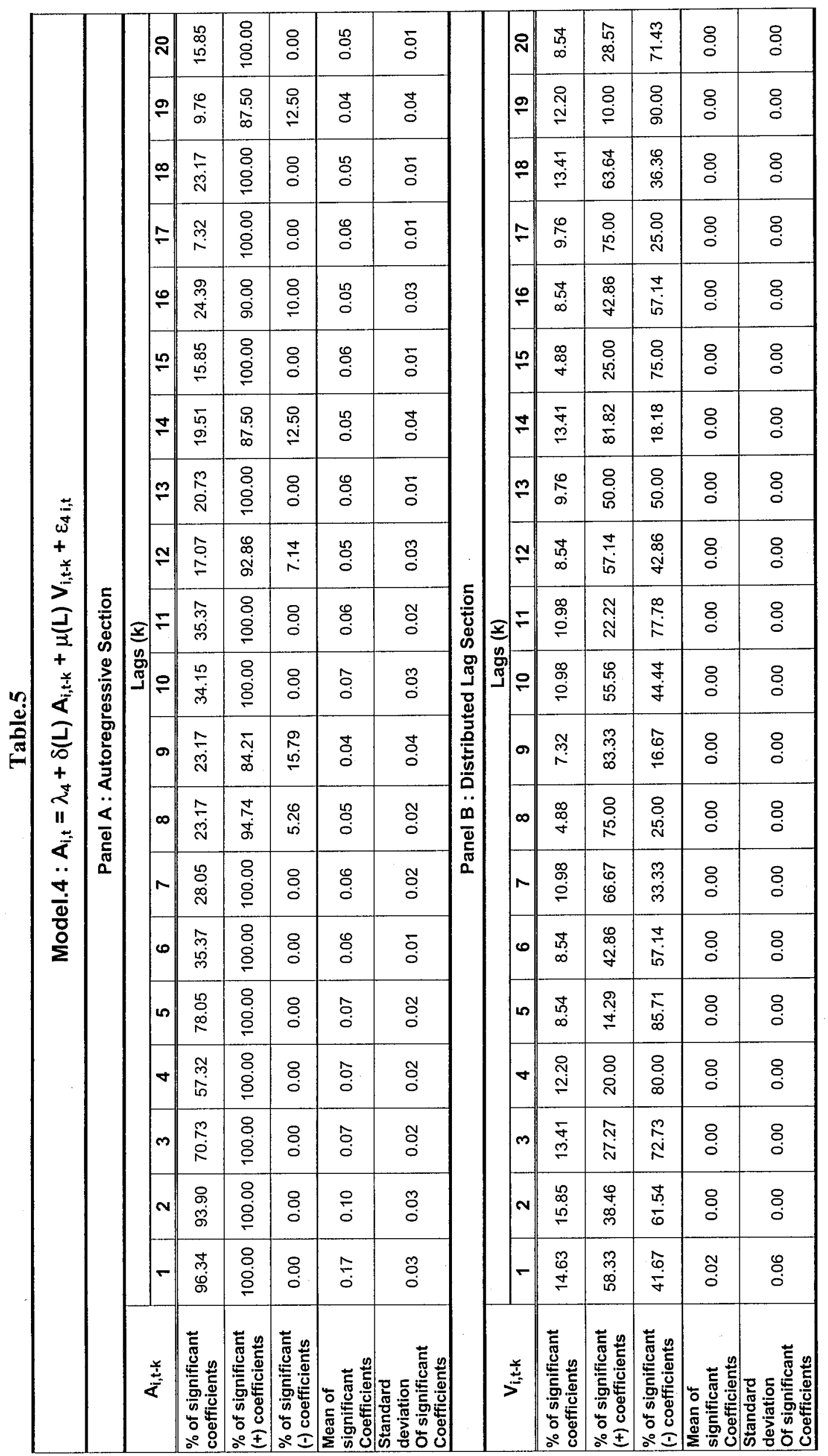




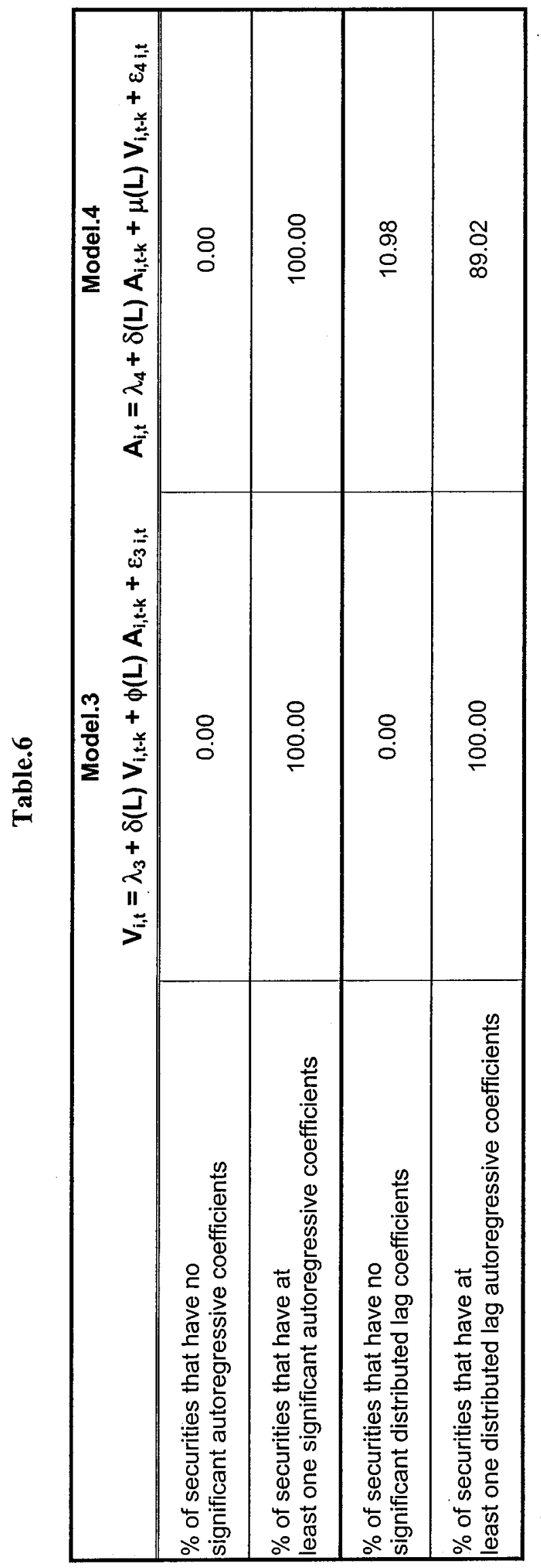

